\title{
Potential implication of IL-24 in lymphangiogenesis of human breast cancer
}

\author{
NATASHA C. FREWER, LIN YE, PING-HUI SUN, SIONED OWEN, KE JI, \\ KATHRYN A. FREWER, RACHEL HARGEST and WEN G. JIANG
}

\begin{abstract}
Metastasis and Angiogenesis Research Group, Cardiff University School of Medicine, Cardiff CF14 4XN, UK
\end{abstract}
Received December 12, 2012; Accepted February 4, 2013

DOI: $10.3892 / \mathrm{ijmm} .2013 .1319$

\begin{abstract}
Lymphangiogenesis is involved in the dissemination of malignant cells from solid tumours to regional lymph nodes and possibly to various distant sites. Lymphangiogenesis is regulated by vascular endothelial growth factor (VEGF)-C and VEGF-D. Interleukin (IL)-24 is known as a cytokine with potent antitumour and tumour-suppressive activity which functions through its receptor (IL-22R). Expression of IL-24 has been shown to be reduced in breast cancer, and the reduced expression is associated with lymphatic metastases and a poor prognosis. However, the involvement of IL-24 in lymphangiogenesis during lymphatic metastasis remains unclear. The aim of the present study was to determine whether there is an association between IL-24, IL-22R and lymphangiogenic factors and markers in breast cancer. Analysis of IL-24, IL-22R and lymphangiogenic factors in malignant breast tissue samples $(n=127)$ revealed a correlation between increased expression of lymphangiogenic markers (podoplanin, Prox-1 and LYVE-1) and reduced levels of IL-24 and IL-22R. Samples stained with a high degree of positivity for lymphangiogenic factors and markers whereas staining for IL-24 was weak. In vitro assays showed that the average perimeter length of microtubules formed by endothelial cells treated with IL-24 was significantly reduced compared to the control. The growth of endothelial cells was significantly reduced when exposed to a high concentration of IL-24 $(250 \mathrm{ng} / \mathrm{ml})$. Treatment of HECV cells with IL-24 resulted in significantly reduced expression of VEGF-C $(\mathrm{P}<0.05)$ and VEGF-D $(\mathrm{P}<0.001)$. In conclusion, reduced expression of IL-24 and IL-22R in breast cancer is correlated with increased expression of specific lymphangiogenic markers. IL-24 suppressed in vitro growth and microtubule formation of endothelial cells. IL-24 may downregulate the expression of lymphangiogenic markers and
\end{abstract}

Correspondence to: Professor Wen G. Jiang, Metastasis and Angiogenesis Research Group, Cardiff University School of Medicine, Cardiff CF14 4XN, UK

E-mail: jiangw@cf.ac.uk

Key words: interleukin-24, MDA-7, lymphangiogenesis, breast cancer factors although further research is required. This suggests that IL-24 plays a profound role in suppressing tumour lymphangiogenesis, thereby, reducing the likelihood of cancer metastasis via the lymphatic route.

\section{Introduction}

Lymphangiogenesis is the process by which new lymphatic vessels form from pre-existing lymphatic vessels or lymphatic endothelial progenitor cells (1). The process is important in the normal development of the lymphatic system and is also implicated in pathological processes such as inflammation, lymphedema and importantly cancer metastasis. The lymphatic vasculature serves as a major route for the dissemination of malignant cells from solid tumours, particularly to regional lymph nodes (2). The extent of lymph node metastasis is a major determinant of both staging and prognosis in breast cancer.

The recent discovery of a number of molecular and cellular markers thought to be specific to lymphatic endothelial cells has enabled more detailed research into lymphangiogenesis. The most important lymphangiogenic markers include podoplanin (a glomerular podocyte membrane mucoprotein) (3), Prox-1 (a homeobox gene involved in embryonic development of the lymphatic system) (4) and LYVE-1 (a marker shown to be found exclusively on lymphatic vessels in normal tissues and tumours) (5). Several studies have reported that high expression levels of lymphangiogenic markers (particularly podoplanin and LYVE-1) in breast tumours are correlated with increased lymphatic vessel density, increased likelihood of tumour metastasis to regional lymph nodes and therefore a poor prognosis (6-9).

The process of lymphangiogenesis is thought to be regulated by the interaction of vascular endothelial growth factor (VEGF)-C or VEGF-D with the cell surface receptor VEGFR-3 (2). Research suggests that VEGF-C expression in breast cancer may correlate with increased lymph node metastases (10) and significantly poorer disease-free survival (assessed at five years) (11). In contrast, other studies have indicated that a high VEGF-C to VEGF-D ratio in breast tumours may be a more accurate predictor of increased likelihood of lymph node metastasis (12-14). High expression levels of lymphangiogenic factors or markers may be important in indicating an increased potential for lymphangiogenesis and cancer metastasis. 
Interleukin (IL)-24 is a member of the IL-10 cytokine family. The secreted protein is 206 amino acids in length and has a predicted size of 35-40 kDa (15). Previous studies suggest that IL-24 operates through interaction with IL-20R1/ IL-20R2 or IL-22R1/IL-20R2 heterodimers $(15,16)$. IL-24 was originally detected in human melanoma cells. However, it appears to be lowly expressed in cells of the immune system, including spleen cells, thymus cells and normal melanocytes (16).

IL-24 is thought to possess antitumour characteristics. By suppressing signals generated by tumour cells and through interference with tumour vasculature, IL-24 may act to inhibit tumour growth and metastasis (17). Forced expression of IL-24 in breast cancer cells was found to cause potent growth suppression (18). Results from in vitro assays suggest that IL-24 significantly reduces migration and motility of breast cancer cells (19).

Immunohistochemical staining has demonstrated that normal breast tissue contains substantially higher levels of IL-24 compared to malignant breast tissue. Lower transcript levels of IL-24 were found to be correlated with node-positive breast tumours, increased likelihood of distant metastasis, a poor prognosis and shorter disease-free survival. Patients with higher levels of IL-24 were more likely to have a better prognosis and remain alive and disease-free (19). The correlation between loss of IL-24 expression and increased tumour invasion may indicate that IL-24 has an important role in tumour suppression. However, how IL-24 is involved in lymphatic metastasis remains unclear.

The aim of the present study was to assess whether there is an association between levels of IL-24, IL-22R and the expression of lymphangiogenic factors and markers in breast cancer tissue samples obtained from a cohort of 127 women. In vitro studies were then carried out to investigate how IL-24 alters the expression of lymphangiogenic factors and markers. The effect of IL-24 on specific functions (growth and microtubule formation) of endothelial cells was also examined.

\section{Materials and methods}

Cohort of tissue samples. Breast cancer tissue samples $(\mathrm{n}=127)$ were collected from patients at the University Hospital of Wales, Cardiff. Ethical approval and informed consent was obtained. RNA extraction of the samples was performed using an RNA extraction kit (AbGene Ltd., Surrey, UK) along with reverse transcription. Pairs of PCR primers were designed using the Beacon Designer ${ }^{\mathrm{TM}}$ software and synthesised by Sigma-Aldrich. IcyclerIQ ${ }^{\mathrm{TM}}$ (Bio-Rad, Hemel Hempstead, UK) was used to carry out real-time quantitative PCR [based on previously described methods $(19,20)]$ to detect transcript levels of IL-24, IL-22R and lymphangiogenic factors and markers in the breast cancer samples. The Amplifluor system (Intergen Inc., New York, NY, USA) was utilized under the following conditions: an initial period of $15 \mathrm{~min}$ at $95^{\circ} \mathrm{C}$ followed by 60 cycles of $95^{\circ} \mathrm{C}$ for $15 \mathrm{sec}, 55^{\circ} \mathrm{C}$ for $60 \mathrm{sec}$ and $72^{\circ} \mathrm{C}$ for $20 \mathrm{sec}$ together with QPCR Master Mix (ABgene, Surrey, UK).

Materials and cell lines. HECV cells purchased from Interlab (Milan, Italy) were maintained in Dulbecco's modified Eagle's medium (DMEM) (Sigma-Aldrich, Poole, UK) supplemented with benzylpenicillin, amphotericin B, streptomycin and $10 \%$ fetal bovine serum (Sigma-Aldrich). The cells were incubated at $37^{\circ} \mathrm{C}$ in $5 \% \mathrm{CO}_{2}$ and $95 \%$ humidity until confluent. Matrigel (reconstituted basement membrane) was purchased from Collaborative Research Products (Bedford, MA, USA).

Treatment of cells with IL-24 and conventional and quantitative polymerase chain reaction. Six $12.5-\mathrm{cm}^{2}$ tissue culture flasks were seeded with $1 \times 10^{6} \mathrm{HECV}$ cells and incubated at $37^{\circ} \mathrm{C}$ for $24 \mathrm{~h}$. Cells were treated with $25 \mathrm{ng} / \mathrm{ml}$ human recombinant IL-24 (R\&D Systems Europe) and incubated at $37^{\circ} \mathrm{C}$ for $1,2,4$ and $24 \mathrm{~h}$. Total RNA reagent (TRI) was used to extract the RNA from IL-24-treated cells using the provided protocol (Sigma-Aldrich). RNA was quantified using a spectrophotometer (WPA UV 1101; Biotech Photometer, Cambridge, UK) and standardised to a concentration of $500 \mathrm{ng}$. Reverse transcription was performed using the iScript cDNA synthesis kit (PrimerDesign Ltd., Southampton, UK).

Conventional PCR was carried out in a T-Cy Thermocycler (Creacon Technologies Ltd., The Netherlands) using REDTaq ${ }^{\circledR}$ ReadyMix $^{\mathrm{TM}}$ PCR reaction mix (Sigma-Aldrich), cDNA from cells and the following primers: GAPDH (which served as a control), VEGF-C and VEGF-D (Table I). The reaction conditions used were: $5 \mathrm{~min}$ at $94^{\circ} \mathrm{C}, 40 \mathrm{sec}$ at $94^{\circ} \mathrm{C}, 40 \mathrm{sec}$ at $55^{\circ} \mathrm{C}$, $1 \mathrm{~min}$ at $72^{\circ} \mathrm{C}$ for 35 cycles and $72^{\circ} \mathrm{C}$ for $10 \mathrm{~min}$. PCR products were then stained with SYBR Safe ${ }^{\mathrm{TM}}$ (Invitrogen) separated on a $1 \%$ agarose gel, visualised under UV light and photographed. ImageJ software was used to semi-quantify the results.

Real-time quantitative PCR was carried out using the iCycler $\mathrm{iQ}^{\mathrm{TM}}$ Real-Time detection system (Bio-Rad) to determine transcript levels of VEGF-C, VEGF-D and Prox-1 in IL-24-treated HECV cells. QPCR was carried out in a 96-well plate using a previously described method (21) with 10 pmol sense primer, 1 pmol antisense $\mathrm{Z}$ primer (Table I) and 10 pmol FAM-probe, using a custom Hot-Start QPCR master mix, under the following conditions: $95^{\circ} \mathrm{C}$ for $15 \mathrm{~min}$, followed by 50 cycles at $95^{\circ} \mathrm{C}$ for $15 \mathrm{sec}, 55^{\circ} \mathrm{C}$ for $4 \mathrm{sec}$ and $72^{\circ} \mathrm{C}$ for $15 \mathrm{sec}$. The levels of transcripts were calculated as lymphangiogenic factor or lymphangiogenic marker/GAPDH ratio.

Western blotting. HECV cells $\left(1 \times 10^{6}\right)$ contained in $25 \mathrm{~cm}^{2}$ flasks were treated with IL-24 $(25 \mathrm{ng} / \mathrm{ml})$ for $0,1,2$ or $4 \mathrm{~h}$. HMCSF buffer containing $1 \%$ Triton X-100, $2 \mathrm{mM} \mathrm{CaCl}_{2}$, $100 \mu \mathrm{g} / \mathrm{ml}$ phenylmethylsulfonyl fluoride, $1 \mathrm{mg} / \mathrm{ml}$ leupeptin, $1 \mathrm{mg} / \mathrm{ml}$ aprotinin and $10 \mathrm{mM}$ sodium orthovanadate was used to detach and lyse the cells. Insoluble components were then removed by rotating samples on a wheel for $1 \mathrm{~h}$ and centrifuging at 13,000 x g. The protein samples were blotted onto Hybond-C Extra nitrocellulose membranes (Amersham Biosciences UK Ltd., Bucks, UK). Protein expression of GAPDH and lymphangiogenic factors and markers in the samples were assessed. Antibodies specific to GAPDH, VEGF-C, LYVE-1 (Santa Cruz Biotechnology, Inc., Santa Cruz, CA, USA) and VEGF-D (R\&D Systems Europe) were used. Visualisation of the protein bands was carried out using SuperSignal West Dura Extended Duration substrate chemiluminescent system (Perbio Science UK Ltd., Cramlington, 
Table I. Primer sequences.

\begin{tabular}{lll}
\hline Method & \multicolumn{1}{c}{ Name } & \multicolumn{1}{c}{ Sequences } \\
\hline PCR & VEGF-C F9 & TTTGCCAATCACACTTCCTG \\
VEGF-C R9 & CAGGCACATTTTCCAGGATT \\
VEGF-D F9 & CAGGGCTGCTTCTAGTTTGG \\
VEGF-D R9 & TTCTTCAGGGATCTGGATGG \\
& GAPDH F8 & ATGATATCGCCGCGCTCGTC \\
& GAPDH R8 & GCTCGGTCAGGATCTTCA \\
& VEGF-C F12 & CTACAGATGTGGGGGTTGCT \\
VECR & ACTGAACCTGACCGTACAGTAGCTCGTGCTGGTGTTCA \\
& VEGF-D F12 12 & TCCACATTGGAACGATCTGA \\
& VEGF-D ZR12 & ACTGAACCTGACCGTACACTCCACAGCTTCCAGTCCTC \\
& Prox-1 F11 & AGAGCAGGAAATGGCTGAAA \\
& Prox-1 ZR11 & ACTGAACCTGACCGTACATCCGGTTGTAAGGAGTTTGG \\
GAPDH F & CTGAGTACGTCGTGGAGTC \\
& GAPDH ZR & ACTGAACCTGACCGTACAGAGATGATGACCCTTTTG \\
\hline
\end{tabular}

F, forward; R, reverse; VEGF, vascular endothelial growth factor.

UK) and images were captured using a UVIprochem camera system (UVItec, Cambridge, UK).

The values shown graphically for QPCR, conventional PCR with semi-quantitative analysis and western blotting are expressed as the percentage of decrease in lymphangiogenic transcript expression compared to control cells (the expression in the cells not treated with IL-24 was regarded as baseline, i.e. having $100 \%$ lymphangiogenic factor/marker expression). The change in expression was shown as a percentage (\%) in comparison with the control.

In vitro microtubule formation assay. The processes used were modified from previously published methods $(22,23)$. Briefly, 96-well plates were coated with $100 \mu \mathrm{l} /$ well of Matrigel (diluted in a 1 to 1 ratio with serum-free medium) and incubated for $60 \mathrm{~min}$ to allow the thin gel layer to set. HECV cells $\left(3 \times 10^{4} /\right.$ well) were seeded onto the Matrigel layer. The cells were treated with IL-24 $(2.5,25$ and $250 \mathrm{ng} / \mathrm{ml})$ or a preparation of serum-free medium or normal medium and incubated for 4-6 h to allow tubule formation to occur. Subsequently, the microtubule lengths were visualized under bright light microscopy and quantified (total perimeter length per field) using Image J.

In vitro cell growth assay. The processes used were based on a previously published method (24). HECV cells (3,000/well) were plated into 96 -well plates followed by treatment with IL-24 $(2.5,25$ and $250 \mathrm{ng} / \mathrm{ml})$ and a period of incubation (either overnight or 3 days). The cells were fixed in $4 \%$ formaldehyde and stained with $0.5 \%$ crystal violet. After washing, $10 \%$ acetic acid was added, and the absorbance was determined using a Bio-Tek ELx800 multiplate spectrophotometer (Bio-Tek Instruments Inc., Winooski, VT, USA) at a wavelength of $540 \mathrm{~nm}$. Absorbance was used to represent the cell number.

\section{Results}

IL-24 and the expression of lymphangiogenic factors/markers in breast cancer. Following quantitative determination of the transcripts of IL-24, IL-22R, lymphangiogenic factors and markers in the breast cancer tissues $(12,19)$, correlations among these factors were analysed.

Table II depicts the results where IL-24 and IL-22R are found in the presence of CK19 (a specific epithelial cell marker). Levels of IL-24 and IL-22R were therefore normalised values representative of those found within epithelial-derived malignant breast tissue. High levels of IL-22R were associated with significantly high levels of IL-24 expression $(\mathrm{P}<0.01)$. A significant correlation was evident between increased expression of LYVE-1 and reduced expression of IL-24 (correlation coefficient -0.288) $(\mathrm{P}<0.05)$ in the cohort of breast cancer tissue samples. Similarly, the expression of another lymphangiogenic marker, podoplanin, was also significantly inversely correlated with the expression of IL-24 $(\mathrm{P}<0.01)$ and IL-22R $(\mathrm{P}<0.05)$. Although the expression of other examined lymphangiogenic markers and factors (Prox-1, VEGFR-3 and VEGF-C) also appeared to increase in the tumours with lower expression of IL-24, no statistically significant correlation was noted. VEGF-D, however, a promoter of lymphangiogenesis tended to be positively associated with the expression of IL-24 $(\mathrm{P}=0.03)$.

Both epithelial-derived malignant breast tissue and surrounding stromal cells (including endothelial cells) are important factors in lymphangiogenesis of tumours. Therefore levels of IL-24 and IL-22R (non-normalised) in the cohort of breast cancer tissue samples are also provided in Table II. The expression of all lymphangiogenic factors (VEGF-C and VEGF-D) and lymphangiogenic markers (podoplanin, Prox-1, VEGFR-3 and LYVE-1) was inversely correlated with the expression of IL-24. In contrast VEGF-D, VEGF-C and 
Table II. Correlations between IL-24/IL-22R and lymphangiogenic factors/markers at their transcript levels in breast cancer tissues.

\begin{tabular}{lcc}
\hline Transcript name & IL-24 & IL-22R \\
\hline VEGF-C & $-0.115(\mathrm{P}=0.358) /-0.047(\mathrm{P}=0.684)$ & $0.108(\mathrm{P}=0.384) / 0.120(\mathrm{P}=0.293)$ \\
VEGF-D & $0.324(\mathrm{P}=0.03) /-0.068(\mathrm{P}=0.624)$ & $0.289(\mathrm{P}=0.054) / 0.105(\mathrm{P}=0.449)$ \\
Podoplanin & $-0.332(\mathrm{P}=0.001) /-0.183(\mathrm{P}=0.059)$ & $-0.260(\mathrm{P}=0.011) /-0.094(\mathrm{P}=0.33)$ \\
Prox-1 & $-0.199(\mathrm{P}=0.053) /-0.067(\mathrm{P}=0.486)$ & $-0.057(\mathrm{P}=0.578) / 0.102(\mathrm{P}=0.291)$ \\
VEGR3 & $-0.156(\mathrm{P}=0.131) /-0.046(\mathrm{P}=0.637)$ & $-0.134(\mathrm{P}=0.192) / 0.025(\mathrm{P}=0.792)$ \\
LYVE-1 & $-0.288(\mathrm{P}=0.017) /-0.161(\mathrm{P}=0.145)$ & $-0.039(\mathrm{P}=0.749) /-0.042(\mathrm{P}=0.707)$ \\
IL-22R & $0.268(\mathrm{P}=0.008) / 0.305(\mathrm{P}=0.001)$ &
\end{tabular}

Correlation coefficient data comparing expression of lymphangiogenic factors/markers with expression of IL-24 and IL-22R in samples of breast cancer tissue. The correlation coefficient (P-value) of normalised transcript levels/the correlation coefficient (P-value) of non-normalised transcript levels are shown. Transcripts of each gene normalised against the corresponding CK19 levels, respectively, are shown as a ratio against CK19. VEGF, vascular endothelial growth factor.
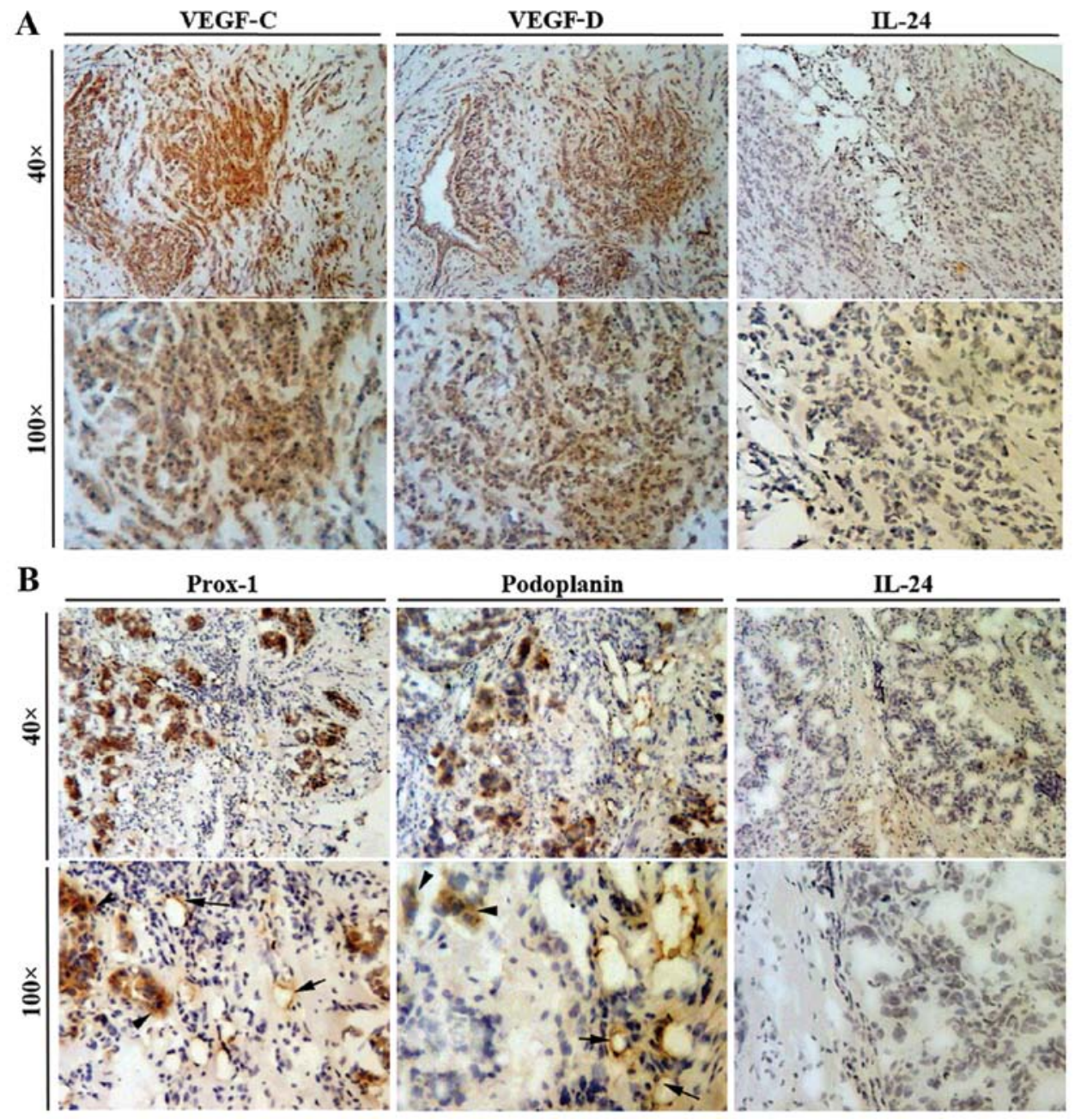

Figure 1. Immunohistochemical staining of IL-24 and lymphangiogenic factors/markers in breast cancer specimens. (A) Breast cancer tissue samples were immunohistochemically stained for the presence of VEGF-C, VEGF-D and IL-24. Breast cancer cells stained positively for VEGF-C and VEGF-D but were virtually negative for the presence of IL-24. (B) Breast cancer tissue samples were immunohistochemically stained for the presence of Prox-1, podoplanin and IL-24. Breast cancer cells (arrowheads) and endothelial cells (arrows) stained positively for Prox-1 and podoplanin but were virtually negative for the presence of IL-24. Shown are the staining of different molecules in the matched specimens.

VEGFR-3 (promoters of lymphangiogenesis) were positively associated with expression of IL-22R. None of the nonnormalised results was found to be significant.
Breast cancer tissue samples were immunohistochemically stained for levels of IL-24 and lymphangiogenic factors (VEGF-C and VEGF-D), IL-24 and lymphangiogenic markers 


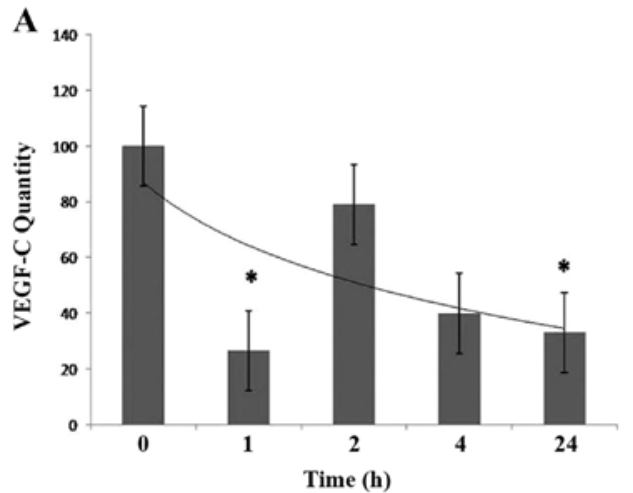

B

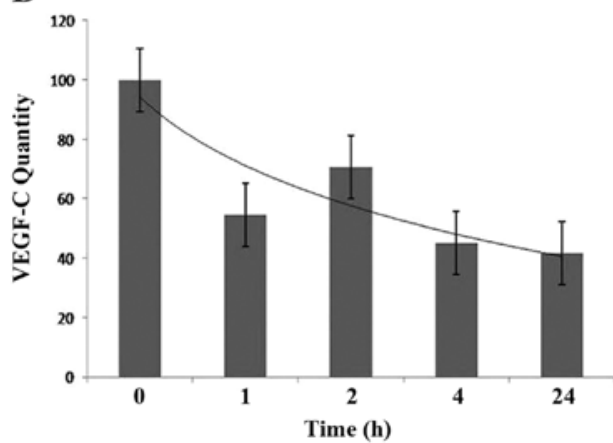

C

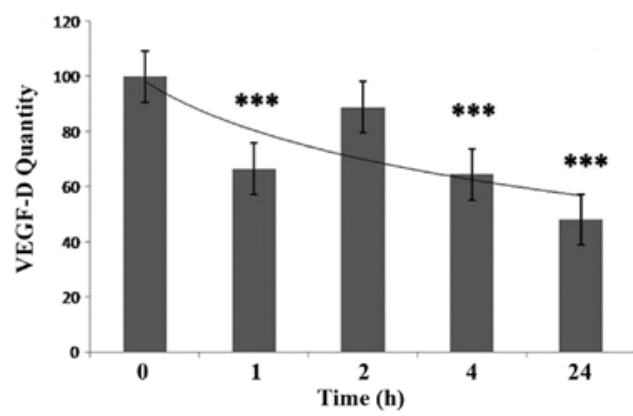

D

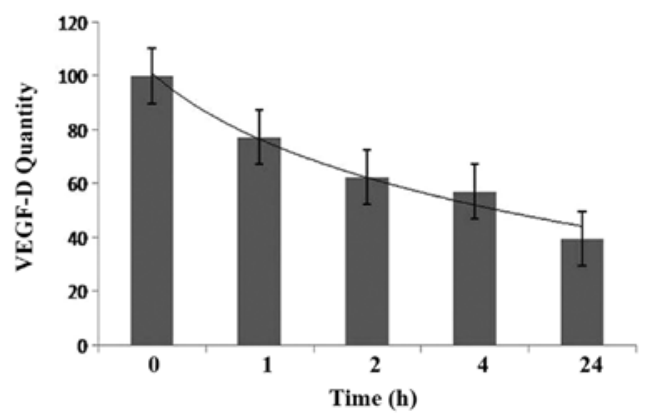

Figure 2. Effect of IL-24 on expression of VEGF-C and VEGF-D in endothelial cells. (A) Semi-quantitative analysis of conventional PCR demonstrating the effect of IL-24 on the expression of VEGF-C in HECV endothelial cells. Treatment of HECV cells with IL-24 for $24 \mathrm{~h}$ resulted in a significantly reduced expression of VEGF-C compared to the control; "P $\leq 0.05$. (B) Quantitative PCR demonstrating the effect of IL-24 on the expression of VEGF-C in HECV endothelial cells. (C) Semi-quantitative analysis of conventional PCR demonstrating the effect of IL-24 on the expression of VEGF-D in HECV endothelial cells. Treatment of HECV cells with IL-24 for 1,4 and $24 \mathrm{~h}$ resulted in significantly reduced expression of VEGF-D compared to the control; *** P $\leq 0.001$. (D) Quantitative PCR demonstrating the effect of IL-24 on the expression of VEGF-D by HECV endothelial cells.

(Prox-1 and podoplanin). A high degree of VEGF-C and VEGF-D positivity was found to be present in breast cancer cells (Fig. 1). In comparison, endothelial cells contained within the tumour tissue did not stain positively for the lymphangiogenic factors VEGF-C and VEGF-D. Fig. 1 also shows that both cancer cells and endothelial cells stained with a high degree of positivity for the lymphangiogenic markers Prox-1 and podoplanin. Breast cancer cells appeared to contain low levels of IL-24 and therefore the staining for this cytokine was very weak or absent from the cancer cells.

Regulation of lymphangiogenic factors/markers in endothelial cells by $I L-24$. Transcript levels of lymphangiogenic factors and markers in the IL-24-treated HECV cells were detected using conventional PCR with semi-quantitative analysis and QPCR. Conventional PCR with semi-quantitative analysis and QPCR demonstrated that treatment of HECV endothelial cells with IL-24 (at a concentration of $25 \mathrm{ng} / \mathrm{ml}$ ) resulted in time-dependent downregulation of VEGF-C and VEGF-D over $24 \mathrm{~h}$. Results obtained using both methods showed the highest levels of mRNA expression of VEGF-C and VEGF-D in the control cells $(0 \mathrm{~h})$. There was rapid and significant downregulation of VEGF-C after $1 \mathrm{~h}$ as detected using semi-quantitative PCR $(\mathrm{P}<0.05)$. This was followed by increased expression of VEGF-C after $2 \mathrm{~h}$ to levels almost equivalent to those detected in the control. A gradual decrease in expression of VEGF-C was then observed after 4 and $24 \mathrm{~h}$ of treatment. At $24 \mathrm{~h}$ significantly reduced levels of VEGF-C were detected using semi-quantitative PCR compared to the control $(\mathrm{P}<0.05)$ (Fig. 2A). QPCR results showed the same trend as those observed using semi-quantitative analysis. No QPCR results, however, were found to be significant, (Fig. 3B). In a same way, semi-quantitative analysis showed levels of expression of VEGF-D to be significantly reduced after $1 \mathrm{~h}$ of treatment with IL-24 $(\mathrm{P}<0.001)$. Significant downregulation of VEGF-D (when compared to control) was then observed at $2 \mathrm{~h}(\mathrm{P}<0.001), 4 \mathrm{~h}(\mathrm{P}<0.001)$ and $24 \mathrm{~h}(\mathrm{P}<0.001)$ (Fig. 2C). Semi-quantitative analysis and QPCR results showed a trend of gradually decreased expression of VEGF-D over the $24 \mathrm{~h}$ period (Fig. 2C and D).

Protein expression of lymphangiogenic factors and markers in the IL-24-treated HECV cells was detected using western blot analysis. The results indicate a time-dependent downregulation of VEGF-C protein expression by IL-24. Levels of VEGF-C protein expression were highest at $0 \mathrm{~h}$ with decreased expression being detected at 1 and $2 \mathrm{~h}$. Significantly low levels of VEGF-C expression (compared to control) were detected after $4 \mathrm{~h}$ of treatment with IL-24 $(\mathrm{P}<0.05)($ Fig. 3). In contrast, levels of VEGF-D and LYVE-1 protein expression appeared to decrease in a time-dependent manner (at 1 and $2 \mathrm{~h}$ ). After 4 h, however, VEGF-D and LYVE-1 expression increased to levels originally detected at time 0 (Fig. 3). Further research is required to elucidate whether downregulation of VEGF-D and LYVE-1 protein expression occurs when HECV cells are treated with IL-24 for a longer period of time (>4 h). 
A

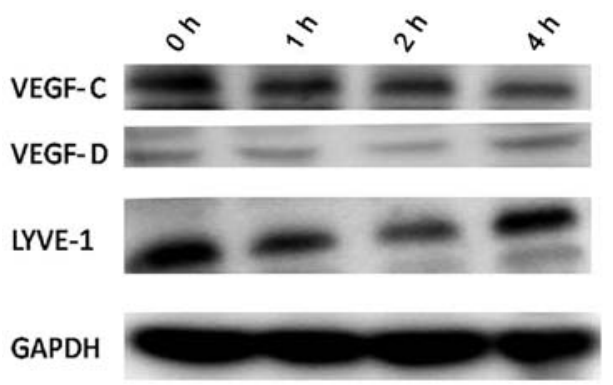

C

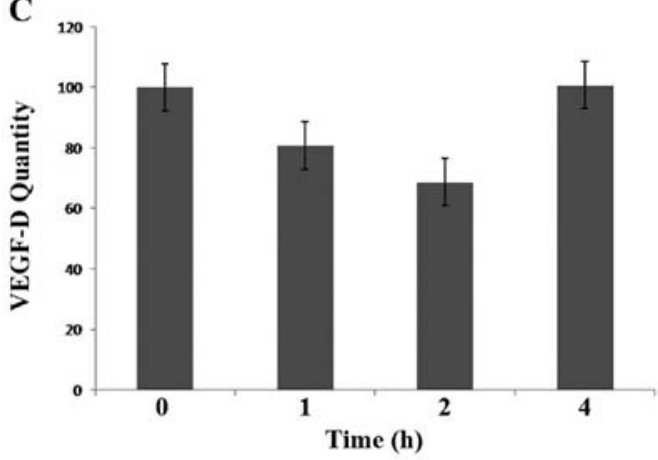

B

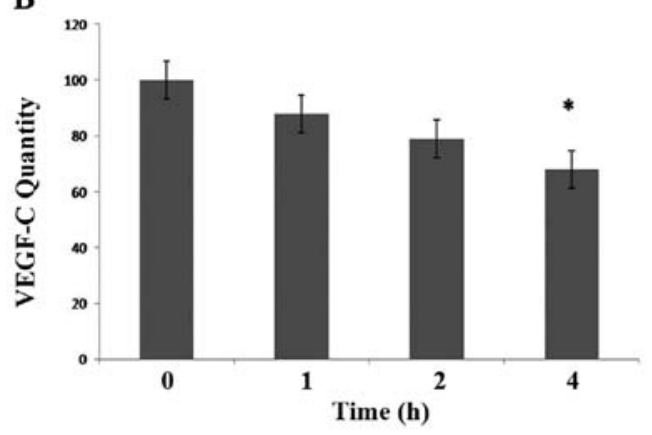

D

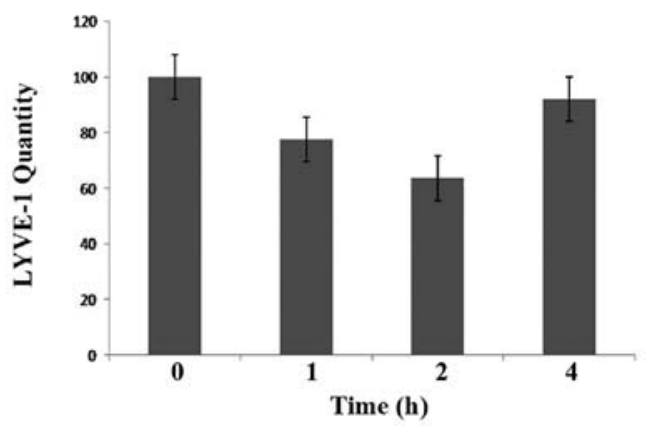

Figure 3. Western blotting demonstrating the effect of IL-24 on protein expression of VEGF-C, VEGF-D and LYVE-1 in HECV endothelial cells. (A) Treatment of HECV cells with IL-24 caused significant downregulation of VEGF-C expression after $4 \mathrm{~h}$ compared to the control; " $\mathrm{P} \leq 0.05$. (B-D) Shown are quantification of the protein bands normalised against the corresponding loading control.
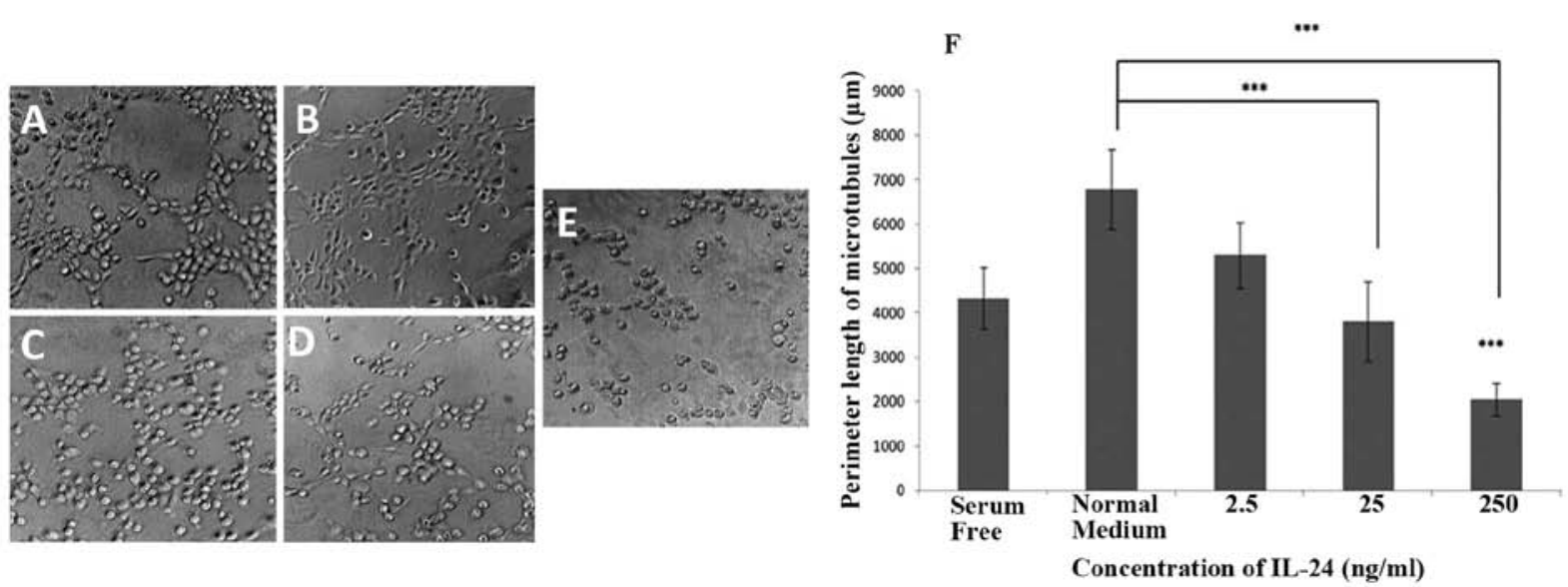

Figure 4. Effect of IL-24 on the ability of HECV endothelial cells to form microtubules. HECV cells were treated with either (A) normal medium as control, (B) serum-free medium as control, (C) $2.5 \mathrm{ng} / \mathrm{ml} \mathrm{IL}-24$, (D) $25 \mathrm{ng} / \mathrm{ml} \mathrm{IL-24} \mathrm{or} \mathrm{(E)} 250 \mathrm{ng} / \mathrm{ml} \mathrm{IL-24.} \mathrm{IL-24} \mathrm{(25} \mathrm{and} 250 \mathrm{ng} / \mathrm{ml}$ ) significantly inhibited tubule formation. (F) Quantitative analysis of the perimeter length of the microtubules formed by HECV endothelial cells treated with IL-24. IL-24 (at a concentration of $250 \mathrm{ng} / \mathrm{ml}$ ) significantly inhibited the formation of microtubules compared to serum-free medium and normal medium; ${ }^{* * *} \mathrm{P} \leq 0.001$. IL-24 (at a concentration of $25 \mathrm{ng} / \mathrm{ml}$ ) significantly inhibited the formation of microtubules compared to the normal medium;*** $\mathrm{P} \leq 0.001$.

IL-24 affects in vitro tubule formation and growth of endothelial cells. IL-24 exhibited a concentration-dependent inhibition on microtubule formation of HECV endothelial cells (Fig. 4). HECV cells that were incubated with normal medium showed the longest perimeter length of microtubules. The most profound reduction in tubule formation was observed in cells treated with the highest concentrations of IL-24 (25 and $250 \mathrm{ng} / \mathrm{ml})$. In the presence of IL-24 at a concentration of $250 \mathrm{ng} / \mathrm{ml}$, microtubule formation of $\mathrm{HECV}$ cells was significantly impaired compared to microtubule formation observed when normal medium was used $(\mathrm{P}<0.001)$ and when serum-free medium was used $(\mathrm{P}<0.001)$. In the presence of IL-24 at a concentration of $25 \mathrm{ng} / \mathrm{ml}$, microtubule formation of HECV cells was significantly impaired compared to microtubule formation in the presence of normal medium $(\mathrm{P}<0.001)$.

HECV cells incubated with normal medium showed relatively high rates of growth between day 1 and day 3 . In comparison, HECV endothelial cells exposed to IL-24 at concentrations of 2.5 and $25 \mathrm{ng} / \mathrm{ml}$ showed reduced growth. 


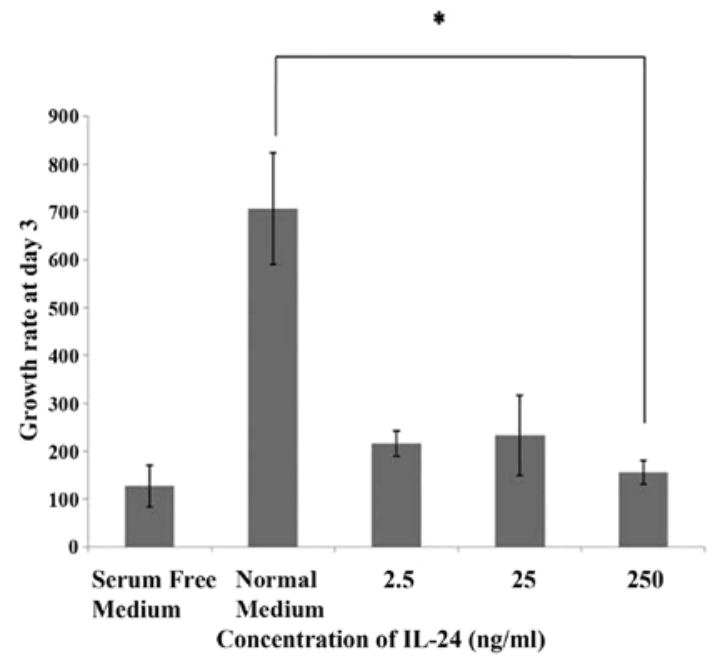

Figure 5. Absorbance results of the growth assay demonstrating the effect of IL-24 on the growth of HECV endothelial cells. IL-24 (at a concentration of $250 \mathrm{ng} / \mathrm{ml}$ ) significantly inhibited the growth of HECV endothelial cells compared to normal medium; ${ }^{\mathrm{P}} \leq 0.05$.

The growth rate observed at day 3 was significantly reduced $(\mathrm{P}<0.05)$ compared to the control when HECV endothelial cells were incubated with a high concentration of IL-24 (250 ng/ml) (Fig. 5).

\section{Discussion}

Results obtained in previous studies suggest a link between loss of IL-24 and increased likelihood of cancer invasion and metastasis particularly in breast cancer (14). IL-24 exerts its effects via IL-22R, a cell surface tyrosine kinase receptor. The present study attempted to ascertain whether loss of IL-24 or IL-22R is associated with increased levels of expression of lymphangiogenic markers and factors in a large cohort of women with breast cancer.

Low expression levels of IL-24 have been found to be associated with significantly higher levels of expression of the lymphangiogenic markers podoplanin $(\mathrm{P}<0.05)$ and LYVE-1 $(\mathrm{P}<0.05)$, and low levels of expression of IL-22R were associated with significantly increased levels of expression of LYVE-1 $(\mathrm{P}<0.05)$. In addition, breast cancer tissue samples were immunohistochemically stained for lymphangiogenic factors and markers and IL-24. Within the tissue samples, cancer cells and endothelial cells stained strongly for VEGF-C and VEGF-D, whereas endothelial cells dislayed a strong positivity for Prox-1 and podoplanin. The tissue samples that stained strongly for lymphangiogenic factors and markers stained very weakly for IL-24. High levels of expression of lymphangiogenic markers and factors found within the tissue samples may indicate a high density of lymphatic capillaries draining the tumour and this may be linked to reduced levels of expression of IL-24. What remains unclear is whether IL-24 has a role in inhibiting the process of lymphangiogenesis of tumours thereby reducing the density of lymphatic capillaries draining the primary cancer and preventing the dissemination of malignant cells to regional lymph nodes.

A number of in vitro assays were carried out to investigate the role of IL-24 in reducing lymphangiogenesis. Results obtained during the present study suggest that IL-24 acts in a time-dependent manner to reduce mRNA expression of lymphangiogenic factors VEGF-C and VEGF-D and the lymphangiogenic marker Prox-1. Within $24 \mathrm{~h}$ of treatment of cells with IL-24, downregulation in the mRNA levels of lymphangiogenic factor and marker were detected. Downregulation of protein expression of VEGF-C was detected after cells were treated with IL-24 for $4 \mathrm{~h}$. In addition, IL-24 had a significant effect on microtubule formation and growth of HECV cells.

The mechanism by which IL-24 exerts anti-lymphangiogenic activity is yet to be fully elucidated. Previous studies suggest that IL-24 operates through interaction with IL-20R1/IL-20R2 or IL-22R1/IL-20R2 heterodimers $(15,16)$. Receptor activation is associated with activation of Janus activated kinase (JAK)/signal transducers and activators of transcription (STAT) signalling. Ramesh et al (17) report that inhibition of microtubule formation is mediated by the interaction of IL-24 with IL-22R1 resulting in the activation of STAT-3. STAT proteins are important in cytokine signalling pathways. Al-Rawi and Jiang (2) suggested that stimulation of VEGFR-3 results in strong activation of STAT-3. It is possible therefore that the regulation of VEGFR-3 signalling (and lymphangiogenesis) can be controlled by other cytokines such as IL-24, although this requires further investigation.

In conclusion, IL-24 significantly inhibits growth and microtubule formation of endothelial cells in vitro and downregulates the expression of some lymphangiogenic factors and markers. By modifying the ability of endothelial cells to function normally, IL-24 may act to impair lymphangiogenesis. In addition to the reduced expression of IL-24 and IL-22R in breast cancer, this is also correlated with increased expression of specific lymphangiogenic factors and markers. This suggests that IL-24 plays a role in vivo to suppress tumour lymphangiogenesis thereby reducing the likelihood of cancer metastasis via the lymphatic route. Further research is however required to fully elucidate the mechanisms by which IL-24 inhibits lymphangiogenesis.

\section{Acknowledgements}

The authors wish to thank the Royal College of Surgeons of England, the Breast Cancer Hope Foundation, the Albert Hung Foundation and the Cancer Research Wales for supporting their study.

\section{References}

1. Skobe M, Hawighorst T, Jackson DG, Prevo R, Janes L, Velasco P, Riccardi L, Alitalo K, Claffey K and Detmar M: Induction of tumour lymphangiogenesis by VEGF-C promotes breast cancer metastasis. Nat Med 7: 192-198, 2001.

2. Al-Rawi MA and Jiang WG: Lymphangiogenesis and cancer metastasis. Front Biosci 16: 723-739, 2011.

3. Weninger W, Partanen TA, Breiteneder-Geleff S, Mayer C, Kowalski H, Mildner M, Pammer J, Stürzl M, Kerjaschki D, Alitalo $\mathrm{K}$ and Tschachler E: Expression of vascular endothelial growth factor receptor-3 and podoplanin suggests a lymphatic endothelial cell origin of Kaposi's sarcoma tumor cells. Lab Invest 79: 243-251, 1999.

4. Wigle JT and Oliver G: Prox1 function is required for the development of the murine lymphatic system. Cell 98: 769-778, 1999. 
5. Mandriota SJ, Jussila L, Jeltsch M, Compagni A, Baetens D, Prevo R, Banerji S, Huarte J, Montesano R, Jackson DJ, Orc L, Alitalo K, Christofori G and Pepper MS: Vascular endothelial growth factor-C-mediated lymphangiogenesis promotes tumour metastasis. EMBO J 20: 672-682, 2001.

6. Choi WW, Lewis MM, Lawson D, Yin-Goen Q, Birdsong GG, Cotsonis GA, Cohen C and Young AN: Angiogenic and lymphangiogenic microvessel density in breast carcinoma: correlation with clinicopathologic parameters and VEGF-family gene expression. Mod Pathol 18: 143-152, 2005.

7. Lee SK, Cho EY, Kim WW, Kim S, Hur SM, Kim S, Choe JH, Kim JH, Kim JS, Lee JE, Nam SJ, and Yang JH: The prediction of lymph node metastasis in ductal carcinoma in situ with microinvasion by assessing lymphangiogenesis. J Surg Oncol 102: 225-229, 2010.

8. Bono P, Wasenius VM, Heikkilä P, Lundin J, Jackson DG and Joensuu H: High LYVE-1-positive lymphatic vessel numbers are associated with poor outcome in breast cancer. Clin Cancer Res 10: 7144-7149, 2004

9. Nakamura Y, Yasuoka H, Tsujimoto M, Imabun S, Nakahara M, Nakao K, Nakamura M, Mori I and Kakudo K: Lymph vessel density correlates with nodal status, VEGF-C expression, and prognosis in breast cancer. Breast Cancer Res Treat 91: 125-132, 2005 .

10. Stacker SA, Achen MG, Jussila L, Baldwin ME and Alitalo K: Lymphangiogenesis and cancer metastasis. Nat Rev Cancer 2: 573-583, 2002

11. Kinoshita J, Kitamura K, Kabashima A, Saeki H, Tanaka S and Sugimachi K: Clinical significance of vascular endothelial growth factor-C (VEGF-C) in breast cancer. Breast Cancer Res Treat 66: 159-164, 2001

12. Cunnick GH, Jiang WG, Douglas-Jones T, Watkins G Gomez KF, Morgan MJ, Subramanian A, Mokbel K and Mansel RE: Lymphangiogenesis and lymph node metastasis in breast cancer. Mol Cancer 7: 23, 2008.

13. Weidner N: Tumour vascularity and proliferation: clear evidence of a close relationship. J Pathol 189: 297-299, 1999.

14. Van den Eynden GG, Van der Auwera I, Van Laere SJ, Huygelen V, Colpaert CG, van Dam P, Dirix LY, Vermeulen PB and Van Marck EA: Induction of lymphangiogenesis in and around axillary lymph node metastases of patients with breast cancer. Br J Cancer 95: 1362-1366, 2006.

15. Huang EY, Madireddi MT, Gopalkrishnan RV,Leszczyniecka M, Su Z, Lebedeva IV, Kang D, Jiang H, Lin JJ, Alexandre D, Chen Y, Vozhilla N, Mei MX, Christiansen KA, Sivo F, Goldstein NI, Mhashikar AB, Chada S, Huberman E, Pestka S and Fisher PB: Genomic structure, chromosomal localisation and expression profile of a novel melanoma differentiation associated (mda-7) gene with cancer specific growth suppressing and apoptosis inducing properties. Oncogene 20: 7051-7063, 2001.
16. Dash R, Bhutia SK, Azab B, Su ZZ, Quinn BA, Kegelmen TP, Das SK, Kim K, Lee SG, Park MA, Yacoub A, Rahmani M, Emdad L, Dmitriev IP, Wang XY, Sarkar D, Grant S, Dent P, Curiel DT and Fisher PB: mda-7/IL/24: a unique member of the IL-10 gene family promoting cancer-targeted toxicity. Cytokine Growth Factor Rev 21: 381-391, 2010.

17. Ramesh R, Mhashilkar AM, Tanaka F, Saito Y, Branch CD, Sieger K, Mumm JB, Stewart AL, Boquoi A, Dumoutier L, Grimm EA, Renauld JC, Kotenko S and Chada S: Melanoma differentiation-associated gene7/interleukin (IL)-24 is a novel ligand that regulates angiogenesis via the IL-22 receptor. Cancer Res 63: 5105-5113, 2003

18. Jiang H, Lin JJ, Su ZZ, Goldstein NI and Fisher PB: Subtract ion hybridization identifies a novel melanoma differentiation associated gene, mda-7, modulated during human melanoma differentiation, growth and progression. Oncogene 11: 2477-2486, 1995.

19. Patani N, Douglas-Jones A, Mansel R, Jiang W and Mokbel K: Tumour suppressor function of MDA-7/IL-24 in human breast cancer. Cancer Cell Int 10: 29, 2010.

20. Jiang WG, Douglas-Jones A and Mansel RE: Expression of peroxisome-proliferator activated receptor-gamma (PPARgamma) and the PPARgamma co-activator, PGC-1, in human breast cancer correlates with clinical outcomes. Int J Cancer 106: 752-757, 2003.

21. Al-Rawi MA, Watkins G, Mansel RE and Jiang WG: The effects of interleukin-7 on the lymphangiogenic properties of human endothelial cells. Int J Oncol 27: 721-730, 2005.

22. Jiang WG, Hiscox SE, Parr C, Martin TA, Matsumoto K, Nakamura T and Mansel RE: Antagonistic effect of NK4, a novel hepatocyte growth factor variant, on in vitro angiogenesis of human vascular endothelial cells. Clin Cancer Res 5: 3695-3703, 1999.

23. Sanders AJ, Ye L, Mason MD and Jiang WG: The impact of EPLIN $\alpha$ (epithelial protein lost in neoplasm) on endothelial cells, angiogenesis and tumorigenesis. Angiogenesis 13: 317-326, 2010.

24. Jiang WG, Hiscox S, Hallett MB, Horrobin DF, Scott C and Puntis MCA: Inhibition of hepatocyte growth factor-induced motility and in vitro invasion of human colon cancer cells by gamma-linolenic acid. Br J Cancer 71: 744-752, 1995. 